\title{
The Abiotic Environment of Heliamphora nutans (Sarraceniaceae): Pedological and Microclimatic Observations on Roraima Tepui
}

\author{
Wolfram Adlassnig $^{1 *}$, Kornelija Pranjić ${ }^{2}$, Edith Mayer $^{3}$, Georg Steinhauser ${ }^{4}$, Flora Hejjas ${ }^{1}$, \\ and Irene K. Lichtscheidl ${ }^{1}$ \\ ${ }^{1}$ University of Vienna; Institution of Cell Imaging and Ultrastructure Research; Althanstrasse 14; A-1090 Vienna - \\ Austria. ${ }^{2}$ University of Vienna; Department of Biochemistry; Dr. Bohrgasse 9; 1030; Vienna - Austria. ${ }^{3}$ Association \\ for the Conservation of Biodiversity in Kazakhstan; 40 Orbita-1; 05004; Almaty - Kazakhstan. ${ }^{4}$ Vienna University of \\ Technology; Atominstitut der Österreichischen Universitäten; Stadionallee 2; A-1020; Vienna - Austria
}

\begin{abstract}
The aim of this study was the study of the abiotic environment of the carnivorous pitcher plant Heliamphora nutans (Sarraceniaceae), including the microclimate and the geochemistry of the soil of the growing sites on Roraima Tepui and discuss their relevance within the recent model of carnivorous plant ecology. The soil was peaty and low in nutrients. The microclimate on the site was very balanced, with moderately cool temperatures, a constant high humidity and very low wind speed. Heliamphora was not exposed to any recognizable climatic stress. Previous macroclimatic measurements reflected the growth conditions of Heliamphora only incorrectly, since humidity decreased drastically with height. The apparent conflict with the common model of carnivorous plant ecology was caused by the dense surrounding vegetation. However, the leaf coverage of these non carnivorous plants was too low to cause significant insolation decrease for Heliamphora. Furthermore, the temperature regime of the pitcher fluid was more balanced than the temperature of the leaf. This may improve conditions for the growth of microorganisms in the pitcher fluid that contribute to the degredation of the plant's prey.
\end{abstract}

Key words: Carnivorous plants, microclimate, soil, niching, competition, cultivation

\section{INTRODUCTION}

Carnivorous plants form a small minority among the vascular plants using a unique strategy to obtain additional nutrients. The capture and utilisation of animals is only profitable under a very specific set of environmental conditions, including high solar radiation, good water supply, oligotrophic substrate and especially lacking competition by neighbouring plants. A model for the niching of carnivorous plants has been developed by Givnish (1984), Benzing (1987) and Ellison et al. (2001; 2005).

Heliamphora nutans (Sarraceniaceae) inhabits the plateaus of several table mountains (Tepuis) of the Guayana Shield in Venezuela, including the Roraima Tepui (Berry et al., 1998). Though some studies on soils (Vaculik et al., 2004) and macroclimate (Maguire, 1970; Tate, 1938) of Tepui habitats in general have been published, only little information is available on the environmental parameters at the growing spots of

\footnotetext{
*Author for correspondence: wolfram.adlassnig@univie.ac.at
} 
Heliamphora. Juniper et al. (1989) report only that the plants grew in wet and peaty depressions which was confirmed by other authors (e. g. Bütschi et al., 1989a, 1989b; George, 1993; Jaffe et al., 1992). However, it is well known that Heliamphora prefers sites with quite dense vegetation, which seems to be controversial to the common model of carnivorous plant ecology (Juniper et al., 1989). Thus, the microenvironment of Heliamphora provides an excellent test for the current understanding of the niching of carnivorous plants.

Species from tropical mountain habitats tend to be most difficult in cultivation among all carnivorous plants. Detailed information on the conditions at the natural site is crucial for the optimisation of cultivation protocols. The parameters that influence plant growth include soil composition, temperature of air and soil, relative air humidity, air movement and light intensity.

In this study, we present chemical analyses of the soil as well as measurements of the microclimate within a Heliamphora nutans population and discuss their relevance within the current model of carnivorous plant ecology.

\section{MATERIALS AND METHODS}

Measurements were performed at the plateau of Roraima Tepui (05 09.934' N, 60 47.103' W, 2,679 m a. s. 1.) in Venezuela in January 2006. A population of Heliamphora nutans consisting of two clones with together 28 vigorous pitchers growing at the peaty bank of a pond was studied. Soil samples were taken from a depth of $15 \mathrm{~cm}$ in a distance of about $20 \mathrm{~cm}$ from the plants in order to avoid possible root damage. Actual $\mathrm{pH}\left(\mathrm{pH}_{\mathrm{H} 2 \mathrm{O}}\right)$ was determined in a pure water extract using Merck indicator, \# 1.09584.0001; potential pH $\left(\mathrm{pH}_{\mathrm{KCl}}\right)$ was measured in a $1 \mathrm{M} \mathrm{KCl}$ extract. The $\mathrm{KCl}$ extract was also used to determine the content of ammonium (Aquamerck \# 1.09024.0001), nitrite (Aquamerck \# 1.08025.0001), nitrate (Aquamerck \# 1.11170.0001) and phosphate (Aquamerck \# 1.14661.0001).

Neutron Activation Analysis (NAA) was applied to determine the concentrations of some metal ions. The samples were air-dried, transferred to the lab, dried at $60^{\circ} \mathrm{C}$ until constant weight and homogenised in an agate mortar. The samples were weighed into activation vials and activated in the TRIGA Mark II reactor of the Atominstitut by means of neutron bombardment (short and long term activation). After decontamination and necessary cooling, the artificial radionuclides' activity was determined using $\gamma$-spectroscopy in a HPGe- $\gamma$-detector. The application of NAA for element analysis of geological materials as well as a detailed methodological description has been described by Steinhauser et al. (2006). CANMET Reference Soil SO 1, Light Sandy Soil BCR No. 142 and MC rhyolite GBW07113 multielement standards were used for calibration.

Climatic parameters were measured every hour for two days within each Heliamphora clone as well as two meters above the ground on a nearby site without vegetation as in standardised climatic measurements (Berényi, 1967). Air temperature, soil temperature $(10 \mathrm{~cm}$ below the surface) and air humidity (all using a Multifunctional Environmental Measurement Tool Conrad ID127700), wind speed (Anemometer ID-42010079TFA), solar radiation (LT-Lutron LX-107) as well as trap and soil surface temperature (Voltcraft IR270L) were monitored. The temperature of the pitcher fluid was determined using an ethanol thermometer. A more detailed description of the microclimatic measurements is given by Adlassnig et al. (2006).

\section{RESULTS}

All Heliamphora plants found on Roraima Tepui, including both test clones, grew within relatively dense vegetation usually consisting of grasses, Eriocaulon sp. (Eriocaulaceae), Stegolepis guianensis (Rapataceae) etc. (Fig. 1). At open, rocky and sandy sites, which were much more typical for the plateau, Heliamphora was not found. At the test sites, the soil consisted of sandy peat densely penetrated by roots. The peat was soaked with water but not flooded. No soil layers could be distinguished. The composition of the soil is given in Table 1. In general, the soil was moderately acidic and poor in nutrients. Toxic elements like heavy metals were found only in traces.

The microclimate at the Heliamphora site proved to be quite balanced. This is true especially in comparison with the microclimate of another carnivorous plant, Drosophyllum lusitanicum, where temperature and solar radiation can reach 
much higher values (Adlassnig et al., 2006; Peroutka et al., 2005).

The temperature was always moderately cool, and the relative air humidity was high. Though the weather was sunny at least part of each day, no extremely high solar radiation was measured. Throughout the measurements at the end of the rainy season, it was sunny in the morning until noon, when temperature and solar radiation reached their maxima and humidity its minimum. At noon, always fog and sometimes rain were observed, and solar radiation decreased drastically. In the afternoon, more or less sunny conditions were found again (Fig. 2). In the evening, as well as in the morning, temperature was cool but always well above $0^{\circ} \mathrm{C}$, and air humidity was next saturation. These macroclimatic data were consistent with earlier studies (Maguire et al., 1948; Maguire, 1970; Tate, 1938) and seem to be typical for the season.

Concerning air temperature and solar radiation, no significant differences between the conditions within the Heliamphora population and $2 \mathrm{~m}$ above was found. Air humidity, however, was more than two times higher next to the Heliamphora plants. The humidity decreased abruptly about $1.7 \mathrm{~m}$ above the ground. Interestingly, this was also the maximum height of Bonnetia trees at the test site. The wind speed could not be measured continuously, but was always very low and almost zero within the Heliamphora population.

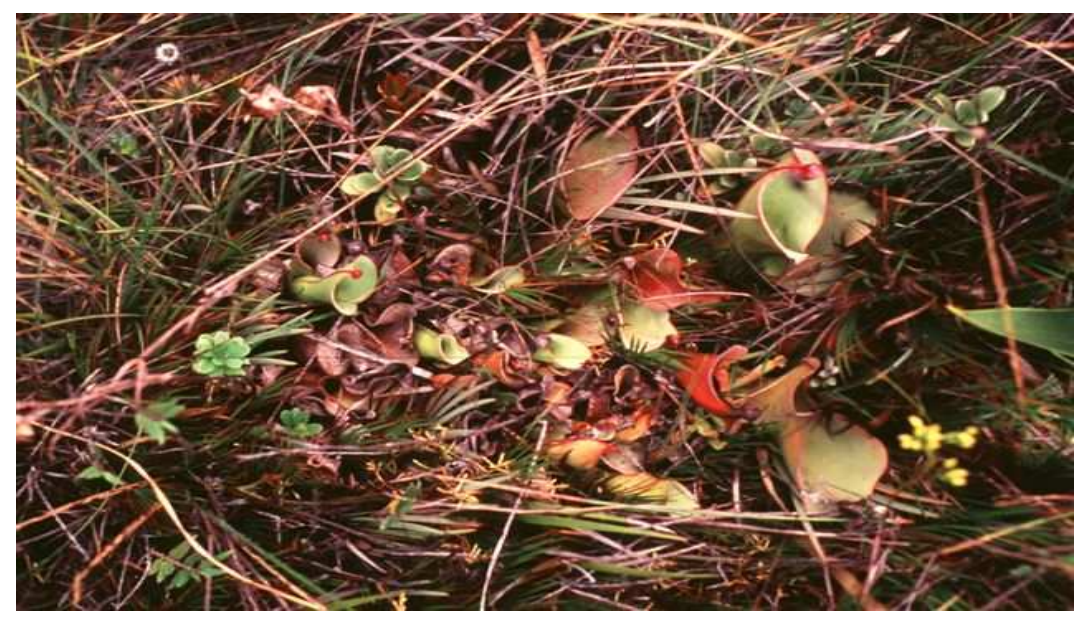

Figure 1 - Heliamphora nutans within a dense vegetation of non carnivorous plants.

Table 1 - Chemical composition of Heliamphora soil, including the concentrations of inorganic nutrients and some heavy metals detectable by NAA.

\begin{tabular}{|c|c|c|c|}
\hline Water holding capacity & $\approx 400 \%$ & Copper & Not detected \\
\hline $\mathrm{pH}_{\mathrm{H} 2 \mathrm{O}}$ & 4.0 & Potassium & $239 \mathrm{mg} \cdot \mathrm{kg}^{-1}$ \\
\hline $\mathrm{pH}_{\mathrm{KCl}}$ & $3.75-4.0$ & Sodium & $52 \mathrm{mg} \cdot \mathrm{kg}^{-1}$ \\
\hline Conductivity (Soil water) & $5 \mu \mathrm{S} \cdot \mathrm{cm}^{-1}$ & Manganese & $7 \mathrm{mg} \cdot \mathrm{kg}^{-1}$ \\
\hline Ammonium & Not detected & Lutetium & $0.013 \mathrm{mg} \cdot \mathrm{kg}^{-1}$ \\
\hline Nitrite & Not detected & Uranium & $0.1 \mathrm{mg} \cdot \mathrm{kg}^{-1}$ \\
\hline Nitrate & Not detected & Dysprosium & $0.2 \mathrm{mg} \cdot \mathrm{kg}^{-1}$ \\
\hline Phosphate & $0-0.25 \mathrm{mg} \cdot \mathrm{kg}^{-1}$ & Samarium & $0.2 \mathrm{mg} \cdot \mathrm{kg}^{-1}$ \\
\hline
\end{tabular}

The soil was slightly cooler than the air, but its temperature changed much less in the course of the day. The soil surface, however, was always several degrees colder than the air and the soil $10 \mathrm{~cm}$ below as it was shadowed by the plants.

The temperature household of the plant exhibited an astonishing feature: Though the mean temperatures of the air, the pitcher surface and the pitcher fluid did not differ, the pitcher surface exhibited the bigger changes during the day, whereas the temperature of the fluid was more balanced (Fig. 3). Altogether, the temperature changes of the fluid were only $60 \%$ of that of the pitcher surface.

Mean and extreme values of the measurements are given in Table 2. 


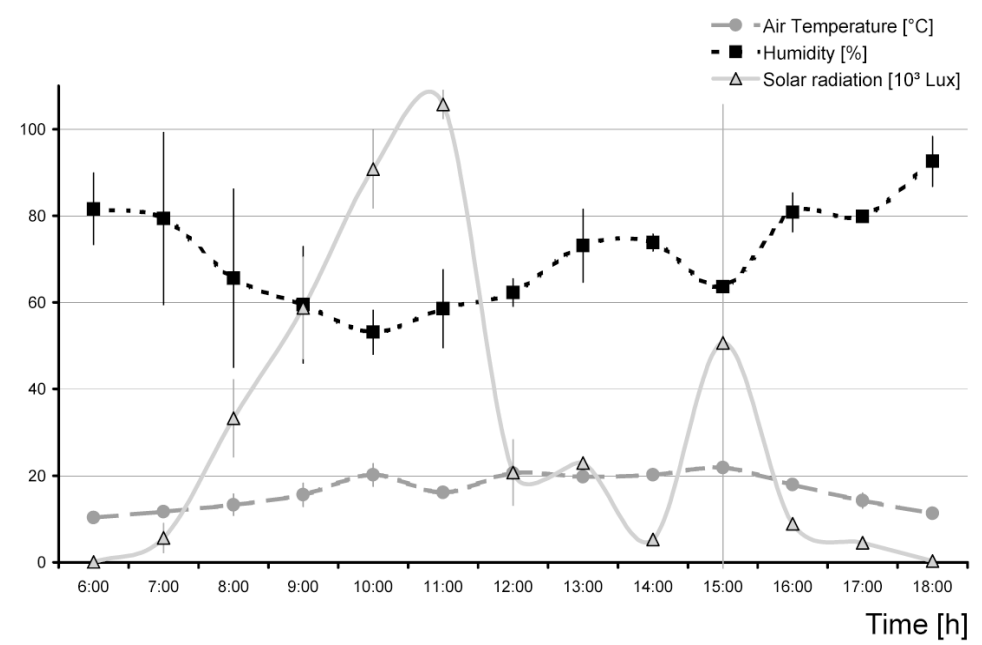

Figure 2 - Changes of air temperature, relative air humidity and solar radiation measured next to Heliamphora plants during two days.

Table 2 - Mean and extreme values of the climatic parameters measured on the test site.

\begin{tabular}{lccc}
\hline \multicolumn{1}{c}{ Parameter } & Minimum & Maximum & Average \\
\hline Air temperature (next to Heliamphora) & $9.7^{\circ} \mathrm{C}$ & $25.7^{\circ} \mathrm{C}$ & $16.4^{\circ} \mathrm{C}$ \\
Air temperature (2 m above) & $10.1^{\circ} \mathrm{C}$ & $24.1^{\circ} \mathrm{C}$ & $16.4^{\circ} \mathrm{C}$ \\
Soil temperature (surface) & $6^{\circ} \mathrm{C}$ & $23^{\circ} \mathrm{C}$ & $13.4^{\circ} \mathrm{C}$ \\
Soil temperature (10 cm below surface) & $12.0^{\circ} \mathrm{C}$ & $20.1^{\circ} \mathrm{C}$ & $15.9^{\circ} \mathrm{C}$ \\
Trap temperature (pitcher surface) & $4^{\circ} \mathrm{C}$ & $28^{\circ} \mathrm{C}$ & $15.1^{\circ} \mathrm{C}$ \\
Pitcher temperature (pitcher fluid) & $7^{\circ} \mathrm{C}$ & $24^{\circ} \mathrm{C}$ & $15.5^{\circ} \mathrm{C}$ \\
Solar radiation (next to Heliamphora) & $41 \mathrm{Lux}$ & $109,000 \mathrm{Lux}$ & $31,300 \mathrm{Lux}$ \\
Solar radiation (2 m above) & $48 \mathrm{Lux}$ & $121,000 \mathrm{Lux}$ & $34,700 \mathrm{Lux}$ \\
Relative air humidity (next to Heliamphora) & $46.0 \%$ & $100.0 \%$ & $71.1 \%$ \\
Relative air humidity (2 m above) & $15.6 \%$ & $89.1 \%$ & $34.2 \%$ \\
Wind speed (next to Heliamphora) & $0.0 \mathrm{~m} \cdot \mathrm{s}^{-1}$ & $0.5 \mathrm{~m} \cdot \mathrm{s}^{-1}$ & \\
Wind speed (2 m above) & $0.0 \mathrm{~m} \cdot \mathrm{s}^{-1}$ & $2.1 \mathrm{~m} \cdot \mathrm{s}^{-1}$ & \\
\hline
\end{tabular}

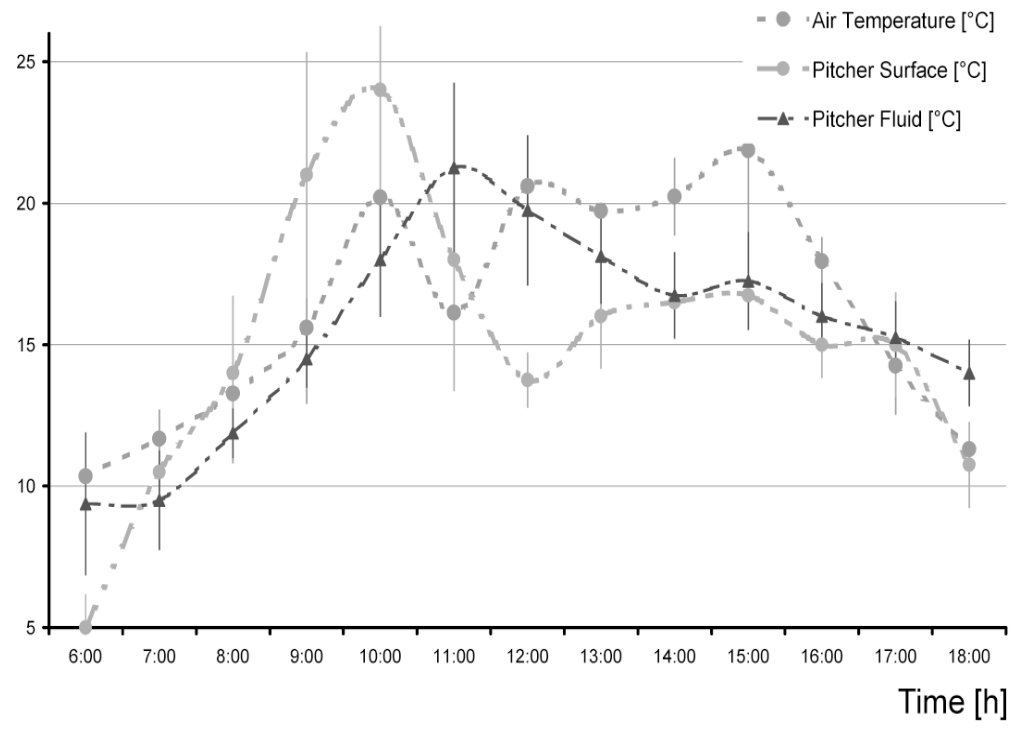

Figure 3 - Comparison of the temperatures of the air, the pitcher surface and the pitcher fluid. 


\section{DISCUSSION}

At first sight, the Heliamphora on Roraima Tepui seems to exhibit quite extraordinary habitat preferences. Typical carnivorous plants tolerate only few vascular plants in their surrounding (Juniper et al., 1989), whereas Heliamphora nutans prefers one of the densest vegetation types available on the plateau. Most carnivorous plants grow on marginal, extremely poor or toxic soils (Adlassnig et al., 2005), whereas Heliamphora is restricted to sites with thick and, compared to the rest of the plateau, well developed soils. The well established model of carnivorous plant ecology (Givnish, 1984, Benzing, 1987, Ellison and Gotelli, 2001, Ellison, 2005) predicts that carnivorous plants require (1) oligotrophic soil, (2) good water supply, either through wet soil or atmospheric water and (3) full sun light. Their need for high light intensities and their slow growth make carnivorous plants extremely intolerant against competition. Do the habitat preferences of Heliamphora nutans disprove the well established model of carnivorous plant ecology, as described by Givnish (1984), Benzing (1987) and Ellison and collaborators (2001; 2005)?

Only exact measurements of abiotic environmental factors demonstrated that Heliamphora clearly confirms the model in spite of the dense vegetation. The elemental composition of the substrate was quite similar to the peat found in temperate bogs (Naucke, 1990). Phosphorus and trace elements are found at least in little amounts, whereas nitrogen was below the limit of detection; thus the need for carnivory was obvious.

The water supply on the test site was excellent. (1) Due to the high water level, the soil contained about $80 \%$ water, (2) the relative air humidity was high throughout the day within the Heliamphora population, though the air became quite dry $1.7 \mathrm{~m}$ above, (3) the wind speed was negligible, thus, transpiration was further minimised. Unlike in more exposed sites on Tepui plateaus, as observed by Porembski and Barthlott (2000) and in the frame of this study, no visible signs of desiccation could be found after several days without precipitation. As a consequence, Heliamphora proves to be very sensitive towards drought and dry air in cultivation (Slack, 2000).

The dense vegetation surrounding Heliamphora does not contradict to the common model for three reasons: (1) In the soaked wet peat, competition for water does not occur. (2) Competition for minerals is not necessary, since Heliamphora supplies itself partly with insect prey. (3) Competition for light obviously does not exist as well, since the solar radiation was only insignificantly reduced by the other plants, even if some of them where considerably larger than the pitchers. Obviously, the leaf area index was so low that no significant shadowing occurred.

Heliamphora's preference for the most favourable spots within the plateau may have an additional reason: according to a model of Ulanowicz (1995), carnivory yields the highest benefit under moderately, but not extremely oligotrophic conditions.

The balanced temperature regime of the pitcher fluid is of special interest. Since Heliamphora does not form its own digestive enzymes, prey degradation depends on the activity of mutualistic microorganisms within the pitcher phytotelm (Pranjić et al., 2007). As demonstrated by Laessle (1961), the diversity of phytotelm inquilines is decreased by drastic daily changes of the temperature. By avoiding extremely high temperatures of the pitcher fluid, Heliamphora probably supports the establishment and activity of its symbionts.

Since each Heliamphora pitcher contained only about $5.5 \mathrm{ml}$ of fluid (data not shown here), the heat capacity of the fluid does not sufficiently explain the balanced temperature regime. Apparently, the pitcher milieu is further stabilised by the geometry of the pitcher shape. A similar effect has been described for the closely related Sarracenia purpurea (Kingsolver 1979, 1981).

\section{ACKNOWLEDGEMENTS}

Thanks are due to M. Peroutka (University of Vienna) for proofreading the manuscript. This study was supported by grant H-2130/2006 of the Hochschuljubiläumsstiftung der Stadt Wien für die Österreichische Akademie der Wissenschaften and by grant 06/9029 of the Österreichische Forschungsgemeinschaft (Austria).

\section{REFERENCES}

Adlassnig, W.; Peroutka, M.; Lichtscheidl, I. K. and Lambers, H. (2005), Roots of carnivorous plants. Plant Soil, 274, 127 - 140 
Adlassnig, W.; Peroutka, M.; Eder, G.; Pois, W. and Lichtscheidl, I. K. (2006), Ecophysiological observations on Drosophyllum lusitanicum. Ecol. Res., 21, 255 - 262

Benzing, D. H. (1987), The origin and rarity of botanical carnivory. TREE, 2, 364 - 369

Berényi, D. (1967), Mikroklimatologie. Mikroklima der bodennahen Atmosphäre. Gustav Fischer Verlag, Stuttgart

Berry, P. E.; Riina, R. and Steyermark, J. A. (1998), Sarraceniaceae. In Flora of the Venezuelan Guayana. Volume 4: Caesalpinaceae - Ericaceae, eds. P. E. Berry, K. Yatskievych and B. K. Holst. Missouri Botanical Garden Press, pp. 138 -144

Bütschi, L.; Huber, D. and Ammann, K. (1989a), Carnivorous plants of Auyantepui in Venezuela. Carnivorous Plant Newsletter, 18, 15 - 18

Bütschi, L.; Huber, D. and Ammann, K. (1989b), Carnivorous plants of Auyantepui in Venezuela. Part 2. Carnivorous Plant Newsletter, 18, 47 - 51

Ellison, A. M. and Gotelli, M. J. (2001), Evolutionary ecology of carnivorous plants. TRENDS Ecol. Evol., 16, $623-629$

Ellison, A. M. (2005), Nutrient limitation and stoichiometry of carnivorous plants: is it time to reassess the costbenefit model for their evolution? XVII International Botanical Congress, Vienna, $\mathrm{p}$. 137

George, U. (1993), Inseln in der Zeit. VenezuelaExpeditionen zu den letzten weißen Flecken der Erde. Gruner and Jahr, Hamburg

Givnish, T. J.; Burkhardt, E. L.; Happel, R. E. and Weintraub, J. D. (1984), Carnivory in the bromeliad Brocchinia reducta, with a cost/benefit model for the general restriction of carnivorous plants to sunny, moist, nutrient-poor habitats. Am. Nat., 124, 479 497

Jaffe, K.; Michelangeli, F.; Gonzalez, J. M.; Miras, B. and Ruiz, M. C. (1992), Carnivory in pitcher plants of the genus Heliamphora (Sarraceniaceae). New Phytol., 122, 733 - 744

Juniper, B. E.; Robins, R. J. and Joel, D. M. (1989), The carnivorous plants. Academic Press Limited, London

Kingsolver, J. G. (1979), Thermal and hydric aspects of environmental heterogenity in the pitcher plant mosquito. Ecol. Monogr., 49, 357 - 376

Kingsolver, J. G. (1981), The effect of environmental uncertainity on morphological design and fluid balance in Sarracenia purpurea L. Oecologia, 48, 364 $-370$
Laessle, A. M. (1961), A micro-limnological study of Jamaican bromeliads. Ecology, 42, 499 - 517

Maguire, B. and Collaborators (1948), Plant explorations in Guiana in 1944, chiefly to the tafelberg and the Kaieteur plateau - VI. Bulletin of the Torrey Botanical Club, 75, 633 - 671

Maguire, B. (1970), On the flora of the Guayana Highland, Biotropica, 2, 85 - 100

Naucke, W. (1990), Chemie von Moor und Torf. In: Moor- und Torfkunde, ed. Göttlich, K. Schweitzerbart'sche Verlagsbuchhandlung, Stuttgart, pp. 237 - 261

Peroutka, M.; Adlassnig, W.; Eder, G.; Pois, W. and Lichtscheidl, I. K. (2005), Pedological and microclimatic requirements of Drosophyllum lusitanicum. XVII International Botanical Congress, Vienna, pp. 508 - 509

Porembski, S. and Barthlott, W. (2000), Granitic and gneissic outcrops (inselbergs) as centers of diversity for desiccation-tolerant vasculant plants. Plant Ecol., 151, 19 - 28

Pranjić, K.; Adlassnig, W.; Stoecker, K.; Daims, H.; Peroutka, M. and Lichtscheidl, I. K. (2007) A microscopical search for putative mutualistic microorganisms in carnivorous plants. Botanical Microscopy Meeting, Salzburg, p. 69

Slack, A. (2000), Carnivorous Plants. MIT-Press, Yeovil

Steinhauser, G.; Sterba, J. H.; Bichler, M. and Huber, H. (2006), Neutron activation analysis of Mediterrenean volcanic rocks - an analytical database for archeological stratigraphy. Appl. Geochem., 21, 1362 - 1375

Tate, G. H. H. (1938), Auyantepui: Notes on the Phelps Venezuelan expedition. Geographical Review, 28, $452-474$

Ulanowicz, R. E. (1995), Utricularia's secret: the advantage of positive feedback in oligotrophic environments. Ecol. Model., 79, 49 - 57

Vaculik, A.; Kounda-Kiki, C.; Sarthou, C. and Ponge, J. F. (2004), Soil invertebrate activity in biological crusts on tropical inselbergs. Eur. J. Soil Sci., 55, 539 $-549$ 